\title{
气候变化科学评估与全球治理博弯的中国启示
}

\author{
张永香 ${ }^{1 *}$, 巢清尘 ${ }^{1}$, 李婧华 ${ }^{2}$, 黄䂞 ${ }^{* *}$, 周波涛 ${ }^{1,3}$
}

1. 中国气象局国家气候中心, 北京 100081;

2. 中国气象局气象干部培训学院, 北京 100081;

3. 南京信息工程大学气象灾害预报预警与评估协同创新中心，南京 210044

*联系人, E-mail: zhangyx @cma.gov.cn; huanglei@cma.gov.cn

气候变化问题是当今国际社会普遍关注的全球性环 境问题之一. 全球应对气候变化不仅涉及科学问题, 也是 国际政治经济共同涉及的问题. 政府间气候变化专门委员 会(Intergovernmental Panel on Climate Change, IPCC)通过 汇总评估全球范围内气候变化领域的最新研究成果, 为全 球治理提供科学依据及可能的政策建议. IPCC 历次评估报 告都成为气候变化国际谈判的重要科学支撑, 对谈判进程 发挥着重要影响 ${ }^{[1]}$. IPCC 评估报告不仅为各国政府制定相 关的应对气候变化政策与行动提供了科学依据, 同时也是 气候变化科学阶段性成果的总结, 是普通公众了解气候变 化知识的重要途径. 当前, IPCC 已进人第六次评估报告的 编写时期. 这期间 IPCC 将一如既往地通过全球科学家的 努力合作为国际社会提供气候变化科学、影响、适应和减 缓层面的最新评估成果, 探索以解决问题为导向的评估, 通过科学研究寻找解决气候问题之道, 推动各国经济社会 向低碳发展转型.

认知气候变化是一个科学问题, 存在学术之争, 而如 何应对气候变化则与经济增长和社会发展有关, 涉及国家 利益 ${ }^{[2]}$. 全球气候变化治理不仅是涉及全球公共物品的分 配与治理, 还需要当前最新气候变化科学认知的支撑.

《联合国气候变化框架公约》(United Nations Framework Convention on Climate Change, UNFCCC, 简称“公约”)是 首个国际应对气候变化的法律文件. 1992 年“公约”签署后, 全球气候治理体系逐渐确立, 世界各国也开始逐渐行动起 来, 共同应对气候变化的挑战(图 1). 在气候变化国际谈判 过程中, 经常会涉及许多具体的科学问题. 这些科学问题 既是制订“公约”和“议定书”的科学基础, 同时也成为公约 缔约方大会及其附属机构会议的议题框架. 通过梳理 IPCC 历次评估报告的主要结论与公约进展的关系将有助 于我们更好地认识气候变化科学与国际政治治理之间的 关系. 当前, 中国正处于影响全球气候治理的新阶段, 回 顾、分析气候变化科学与国际谈判的交互联动, 将为提升 中国有效参与全球气候治理能力, 掌握国际气候变化话语 权提供参考依据, 同时也为未来我国气候变化总体战略布 局提供思路.

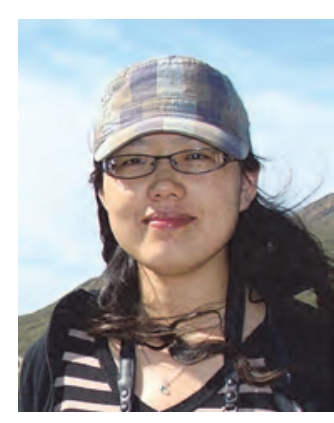

张永香理学博士, 国家气候 中心副研究员, 联合国气候变化框 架公约巴黎能力建设委员会委员. 主要从事历史气候与气候变化政 策科研, 主持和参与国家自然科学 基金、国家重点基础研究发展计划 等多项课题研究，参与联合国气候 变化框架公约和政府间气候变化 专门委员会等相关科技工作。

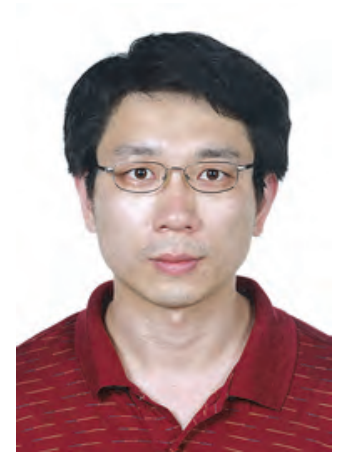

黄品理学博士, 国家气候中 心副研究员, 主要从事气候变化 科研、业务与服务工作。主持国家 重点基础研究发展计划、国家自 然科学基金、中国清洁发展机制 基金等多项课题研究, 参与 IPCC、UNFCCC 相关科技工作, 参加《气候变化国家评估报告》、 《气候变化监测公报》、《气候变 化绿皮书》编写。

\section{IPCC 与公约谈判的互动关系}

\subsection{IPCC 在科学基础上支撑了公约谈判}

政府间气候变化专门委员会(IPCC)自 1990 年以来已 先后发布了 5 次气候变化科学评估报告和一系列特别报 告、方法学报告和技术报告. IPCC 所发布的系列气候变化 评估报告系统地给出了与国际应对气候变化进程密切相 关的科学结论, 代表了国际科学界对气候变化及其影响、 应对的认识水平，具有极强的政策导向性，历来受到国际 社会的高度关注 ${ }^{[3]}$. 通过梳理历次 IPCC 的主要结论与 UNFCCC 的主要进程可见(图 2), 在 UNFCCC 的谈判过程 中, IPCC 的重要结论往往能够在推动谈判进程上起到支撑 


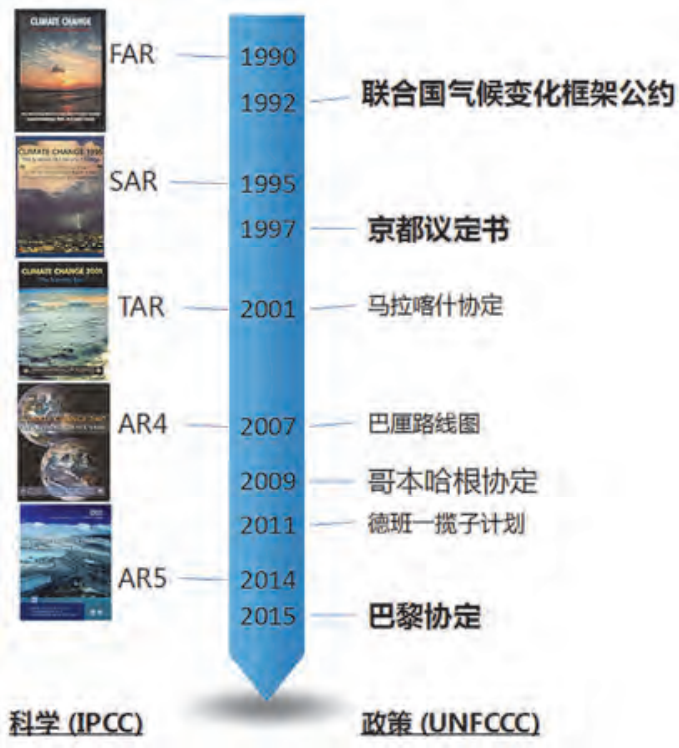

图 1 气候变化科学评估与政策决策的时间进程

Figure 1 Time slots of the scientific assessments and global governance on climate change

作用. IPCC 第一次评估报告(FAR)于 1990 年发布 ${ }^{[4]}$. 该报 告第一次系统地评估了气候变化学科的最新进展, 并从科 学上为全球开展气候治理奠定了基础, 从而推动 1992 年 联合国环境与发展大会通过了旨在控制温室气体排放、应 对全球气候变暖的第一份框架性国际文件“公约”, 明确了
公约第二条. 1995 年发布的 IPCC 第二次评估报告(SAR)尽 管受到了部分质疑, 但却为 1997 年《京都议定书》(Kyoto Protocol, 简称 “议定书”)的达成提供了科学支撑 ${ }^{[5]}$. IPCC 第三次评估报告(TAR)开始分区域评估气候变化影响, 相 应地在 UNFCCC 的谈判中适应议题也逐渐被提高到成为 和减缓并重的应对气候变化途径 ${ }^{[6]}$ (图 2). 2007 年发布的 IPCC 第四次评估报告(AR4)开始将温升和温室气体排放结 合起来, 综合评估了不同浓度温室气体下未来的气候变化 趋势, 为 $2^{\circ} \mathrm{C}$ 被作为应对气候变化的长期温升目标奠定了 科学基础 ${ }^{[7]}$, 尽管 2009 年达成的《哥本哈根协议》并不具 备法律效力, 但经此之后 $2^{\circ} \mathrm{C}$ 温升目标被国际社会普遍承 认. 2014 年完成的 IPCC 第五次评估报告(AR5)进一步明确 了全球气候变暖的事实以及人类活动对气候系统的显著 影响 ${ }^{[8]}$, 为巴黎气候变化大会顺利达成《巴黎协定》奠定 了科学基础 ${ }^{[9]}$. 《巴黎协定》首次凝聚全球各种力量, 推动 各国共同努力实施绿色低碳的可持续发展路径.

\section{2 公约谈判引导了 IPCC 重点评估方向}

尽管联合国气候变化谈判不同于科学研究, 但其往往 又从需求侧为气候变化科学研究指出了重点方向, 在一定 程度上指引了当前科学研究的方向, 并使这些最新结果最 终在 IPCC 的评估报告中得以体现. 以气候谈判中长期目 标的达成为例, 其量化过程就是国际政治谈判引导科学研 究方向并利用科学研究的成果实现政治共识的过程 ${ }^{[10]}$. “公约”第二条以定性描述的方式确立了全球气候治理的长

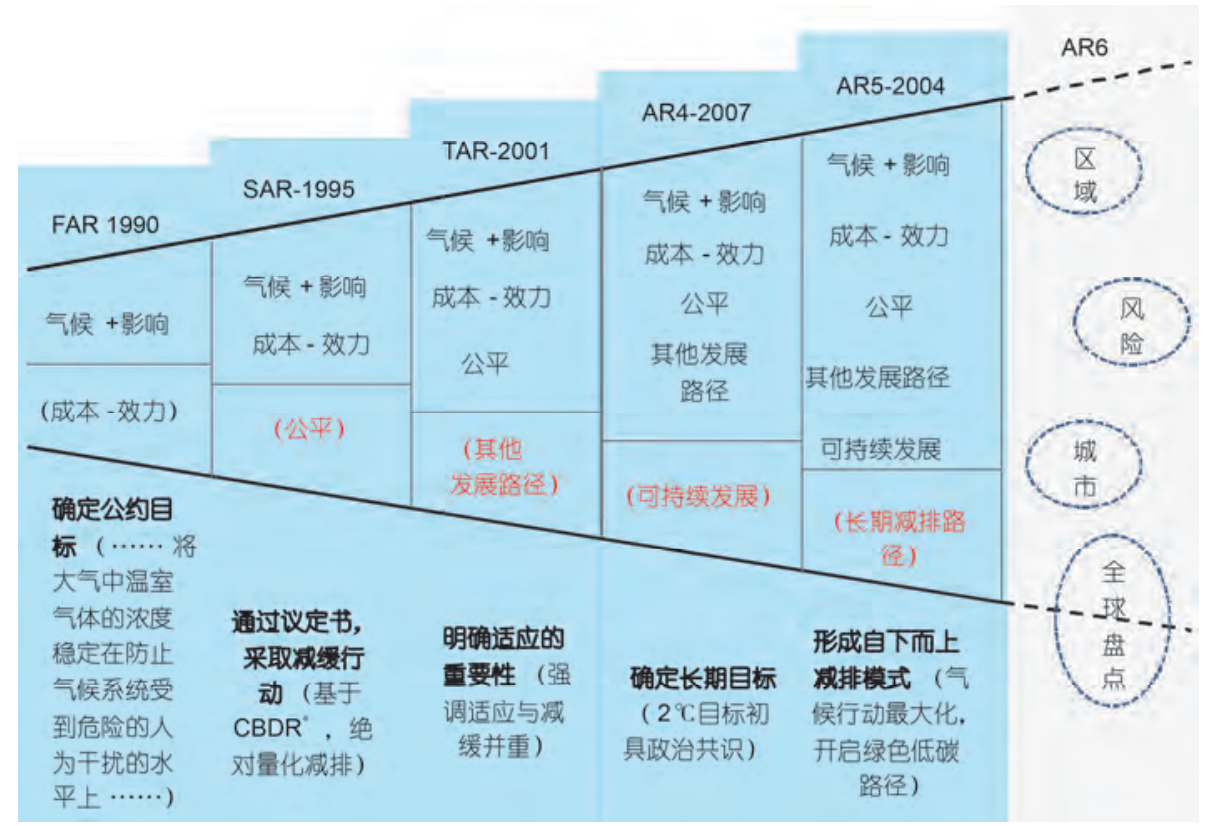

图 2 IPCC 历次报告的主要内容及其与 UNFCCC 重要进程的关系(*表示共同但有区别责任原则)

Figure 2 The main content of the IPCC reports and the main process of the UNFCCC (* denotes the principle of the common but differentiated responsibilities) 
期目标. 而其定量化的过程则是多年政治推动的结果. 以 欧盟为主的政治集团力推长期目标的定量化, 早在 1996 年就首次提出将 $2^{\circ} \mathrm{C}$ 升温阈值作为长期目标; 由于这一目 标无法从 IPCC SAR 中得到有力支持, 因此在当时并未获 得更为广泛的国际认可. 在其后的 IPCC 评估报告中, 欧盟 力推评估温升阈值并将温度目标与排放挂钩, TAR 就涉及 将全球增温控制在 $2^{\circ} \mathrm{C}$ 以内的相关评估结论. AR4 将气候 变化的未来影响直接与温升幅度密切联系起来, 强化了气 候变化风险评估与价值判断对确立长期目标的重要性. 在 欧盟等国家的推动下, 2009 年公约第 15 次缔约方大会达成 了《哥本哈根协议》, 首次明确了 $2^{\circ} \mathrm{C}$ 目标. AR5 首次量化 评估了 $2^{\circ} \mathrm{C}$ 温升目标下的累积排放空间, 指出了实现 $2^{\circ} \mathrm{C}$ 目标的紧迫性和路径. 在一系列气候变化科学评估和政治 推动的基础上, 2015 年达成的《巴黎协定》最终把全球平 均温度上升幅度控制在不超过工业化前水平 $2^{\circ} \mathrm{C}$ 之内的温 升目标正式纳人具备法律效力的国际条约.

除了气候谈判中所遇技术难题在 IPCC 评估报告中能 够得到部分解答外, 应谈判需求, IPCC 还会为解答气候谈 判中的某些具体问题中而组织特别报告. 当前 IPCC 在第 六次评估周期内编写的 3 份特别报告分别为“全球变暖 1.5 ${ }^{\circ} \mathrm{C}$ ”、“气候变化与陆地”和 “气候变化与海洋和冰冻圈”, 其 中“全球变暖 $1.5^{\circ} \mathrm{C}$ ” 特别报告就是应联合国气候变化框架 公约第 21 次缔约方大会邀请而作 ${ }^{[11]}$. 同时, 为了配合公约 谈判进程, 全球变暖 $1.5^{\circ} \mathrm{C}$ 特别报告将于 2018 年 9 月发 布 ${ }^{[12]}$. 此前的研究主要关注重点在 $2^{\circ} \mathrm{C}$ 目标上. $1.5^{\circ} \mathrm{C}$ 特别报 告的评估使得全球的研究重点聚焦于由于《巴黎协定》提出 努力将气温升幅限制在工业化前水平以上 $1.5^{\circ} \mathrm{C}$ 之内的目标. 利用 Web of Science 核心合集数据库对近 10 年公开发表的 关于 $1.5^{\circ} \mathrm{C}$ 研究的 $\mathrm{SCI}$ 论文进行检索, 检索式为 $\mathrm{TS}=(1.5$ NEAR/5 degrees) AND TS=(warming) AND PY=(2007 2017), 文献类型为 article 和 review, 检索日期为 2017 年 12 月 8 日. 结果发现, 在 2016 之后全球关于 $1.5^{\circ} \mathrm{C}$ 研究的 SCI 科研论文增长迅速, 2017 年更是大幅增长(图 3). IPCC 关于 全球变暖 $1.5^{\circ} \mathrm{C}$ 的特别报告将为 2018 年联合国气候变化框 架公约关于促进性对话的谈判提供重要的科学参考.

\section{3 政治因素对 IPCC 的科学评估内容的影响}

IPCC 是一个不依附于任何国家的国际政府间组织, 其开展气候变化评估的科学基础是经过同行评议、公开发 表的科学文献, 理论上不应受到政治影响. 尽管, IPCC 在 其规则设定, 作者遴选等环节均考虑到利益冲突的问题并 设法规避. 但 IPCC 在评估报告的编写程序上规定, 各个工 作组的评估报告都要经过两次专家和政府评审 ${ }^{[13]}$. 在政府 评审中, 各国政府可以就报告内容向写作组提出修正、增 加或删除等修改意见, 而终稿需要根据“协调一致”的原则 经由所有成员国政府的批准, 这就意味着任何一个国家的 拒绝都可能导致评估报告无法通过, 这就使得 IPCC 为了

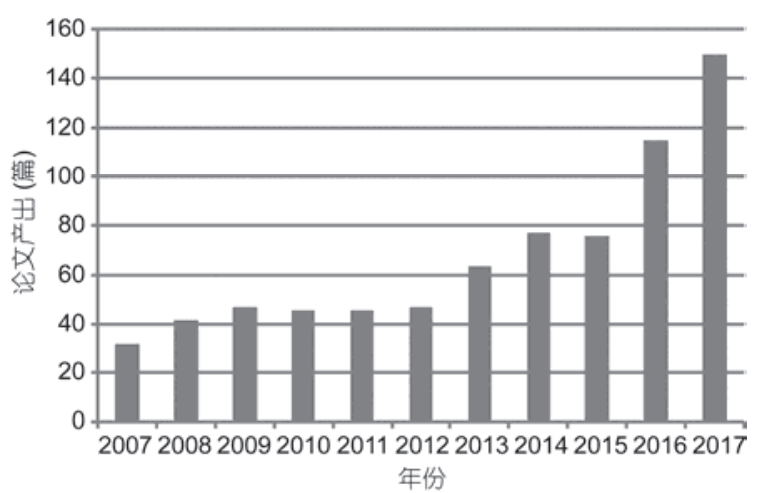

图 3 近 10 年发表的关于 $1.5^{\circ} \mathrm{C}$ 温升 SCI 论文数量

Figure 3 The published SCI paper related with the $1.5^{\circ} \mathrm{C}$ warming in last decade

能够使其报告得以顺利通过，而不得不在报告内容上做出 取舍. 在各工作组报告的撰写上和综合报告的决策者摘要 $(\mathrm{SPM})$ 的审核上, 这种情况更为明显 ${ }^{[14]}$. 因此, 在现实的 运作中, IPCC 所开展的科学评估的内容或多或少都会受到 政治因素的影响. 不可避免地会出现各国家或政治集团要 求增加或删减有关评估内容, 以体现、维护或强化其国家 或政治集团的利益关切.

\section{2 中国在参与 IPCC 与国际气候治理上的不足}

\section{1 科研实力总体仍偏薄弱, 公约谈判中的科学 支撑不足}

IPCC 评估报告无论是对国际气候变化制度建设还是 全球气候变化科学研究都具有重要影响. 作为发展中国家, 中国无论是在气候变化科学研究还是在气候变化外交政 策上总体处于被动地位 ${ }^{[15]}$. 中国科学家对 IPCC 进程的参 与力度和相关研究成果在报告最终成果中的体现程度, 一 定程度上标志着中国在国际气候变化研究领域的水平. 近 些年来, 中国在气候变化研究领域进行了大量投人, 也取 得了很大进展. 对比两次 IPCC 报告可见, AR4 第一工作组 报告中中国大陆作者的引文数量为 $1.4 \%$, 而 AR5 第一工 作组报告中这一引文数翻了 1 倍为 $2.8 \%$. 然而, 中国的总 体科研实力相比欧美等发达国家仍存在一定差距. 除了 AR5 第一工作组报告中中国大陆作者引文数为 $2.8 \%$ 外, 第 二、三工作组报告中大陆作者作为第一作者的引文数量比分 别为 $1.3 \%$ 和 $1.6 \%{ }^{[16 ~ 18]}$. 这与欧美国相比差距巨大. 另外, 在一些核心观点上, 更是几乎没有中国的科研成果体现，如 全球地表气温数据序列、 $2^{\circ} \mathrm{C}$ 温升的累积排放空间等.

中国是世界第一人口大国和第二大经济体，也是世界 上温室气体排放量最大的国家, 长期以来在气候变化谈判 中一直面临着巨大的压力 ${ }^{[19,20]}$. 在气候变化谈判中, IPCC 相关评估结论作为科学基础往往成为发达国家推动谈判进 程的有利武器, 通过科学评估结论和政治推动双管齐下, 对 
排放大国施压, 进而实现其在气候谈判中的政治诉求. 中 国在全球气候治理体系中并不拥有与中国人口和经济规 模相称的话语权, 几乎一直处于被动防御的位置. 尽管中 国具有发展中国家站位的道义优势, 但在气候变化谈判中 常常缺乏有效科学结论的支撑不仅不利于维护国家利益, 也难以体现负责任大国的国际形象.

\subsection{IPCC 与公约谈判结合不够, 长期气候外交 政策仍缺乏设计}

科学研究和气候谈判的关系就像生产商和用户的关系, 而国际话语权有着完整的体系性和层级性. 因此, 一个国家 想拥有国际话语权, 就需要在战略层面进行设计, 并且要积 极参与进去, 才能从内部施加影响. 如前所述, 尽管中国在 近些年不断加大对气候变化科研和政策领域的支持, 但相 对于欧美国家, 中国的气候变化科研实力仍然薄弱, 这也常 常使得在谈判中无弹药可用. 以人均历史累积碳排放为例, 由于温室气体的寿命影响, 当前气候变化的结果是由于历 史时期, 尤其是工业化以来的人为温室气体累积作用的结 果. 从公平的角度来说, 发达国家由于其排放在先必须为其 历史排放担负责任, 实现绝对减排同时为发展中国家提供 补偿. 而发展中国家享有同样的排放权利, 应该以发展为要 务, 并在发达国家历史补偿的基础上尽力减排. 尽管以上理 论在公约文本中有所体现, 但在实际谈判中, 往往受限于发 展中国家对该问题的认识和自身能力, 在这一问题上常无 法达成一致, 谈判进展迟缓甚至倒退.

另外, 尽管中国是发展中国家, 但随着其经济的快速 发展, 目前已成为全球第二大经济体. 发展中大国与发展 中国家在全球气候治理中角色和定位存在较大的差异. 在 不同的经济发展阶段, 如何准确定位中国在全球气候治理 中的角色, 制定系统的长期气候外交政策是现阶段中国的 当务之急. 长期以来中国的发展中国家身份将可能随着其 经济发展而被打破. 当前, 对于中国应引领全球气候治理 的呼声也日渐增强. 然而对于如何实现这一从被动到主动 的角色转换仍缺乏相应的深人研究. 对于气候变化这一特 殊领域, 如何借鉴欧美经验, 利用科学与政策之间的互动 关系, 助力中国实现其长期气候外交策略仍待研究.

\section{3 对中国应对气候变化的启示}

当前全球经济政治环境均出现了新的变化, 传统主导 气候变化规则制定的三方势力也发生了重大变化. 美国现任 总统在应对气候变化领域的不作为和国际气候政策倒退使 得《巴黎协定》开启的全球气候治理的新模式陷人被动 ${ }^{[21]}$. 欧盟则由于其内部经济形势所累, 参与全球气候治理的力度 受限. 发展中国家阵营(G77+中国)由于各自的发展阶段和环 境诉求, 其凝聚力已是貌合神离. 随着经济实力和综合国力 的增强在国际事务上的话语权在不断提升, 中国参与国际气
候变化治理的角色也慢慢发生了变化, 在谈判场上由以往被 动的角色正在走向舞台中央并有望引导未来走向. 在这一上 升期，从战略上总体把握 IPCC 与公约谈判之间的关系将有 助有中国顺利积极地展开气候外交. 目前 IPCC 正在组织撰 写第六次评估报告阶段, 它将为 2023 年开始的全球盘点提供 科学和政策支撑. 同时, 2020 2030 年正是中国进人小康社 会的攻坚阶段, 需要有利的国际大环境给予保障. 因此, 加 强战略谋划, 布局好新阶段的气候科学和谈判工作至关重要.

\section{1 做好顶层设计, 实现科学与政治的紧密结合}

在气候变化问题上, 科学往往是政治决策的前提和基 础, 二者紧密相联. 美国小布什政府退出《京都议定书》 和特朗普政府拟否定《巴黎协定》都打着科学不确定性的 理由. 全面认识和理解科学和政策决策的互动关系, 在气 候变化政策和研究上要整体布局. 气候变化的国际话语权 既需要强大的科学研究实力支撑, 也需要高瞻远瞩的战略 思考, 从战略层面进行设计, 两手齐抓, 才能做到两者相 辅相成. 欧、美、日的学者专业背景强, 既有学术优势, 又 占据语言优势, 还有战略视角, 常常在评估过程中左右着 各种话语权, 在气候谈判中主导谈判进程. 中国在气候变 化政策和研究上要整体布局, 促进科学家与决策者的直接 对话, 提高科学为政策决策服务的效果, 实现科学和政策 互动的利益最大化. 在 IPCC 第六次评估进程中, 中国应做 好整体气候变化战略设计, 理清气候变化外交政策主张与 诉求, 早做科学布局, 呼应中国的气候外交政策.

\section{2 发挥专家智库作用}

鉴于中国当前所处的历史性转折阶段, 气候外交决策 的复杂性前所未有, 迫切需要科学为决策提供前瞻引领、 敏捷精准、权威可信、高质高效的支撑. 欧、美、日等主 要发达国家和地区以及澳大利亚、印度、新西兰等国家都 委任了首席科学顾问以及大量的部门科学顾问, 联合国秘 书长潘基文也于 2013 年成立了科学顾问委员会, 负责为 联合国秘书长和联合国机构的行政首长提供建议. 习近平 总书记也明确提出要“建立健全决策咨询制度”，建立国家 高层次创新决策咨询机制. 通过发挥专家智库作用, 可进 一步增强科学为气候变化外交政策决策服务的支撑能力. 因此, 当前中国需借鉴国内外经典智库的成功经验, 充分 发挥气候变化相关智库的优势, 为中国长期气候外交战略 做好顶层设计和中长期规划.

\section{3 加强科学研究支撑及成果应用推广}

继续保持并增加科研投人，同时强化学术成果的发表 和国际认可度. 未来中国需要更好地加强不同学科的交叉 融合, 注重基础学科研究成果向服务决策的转化. 加强自 然科学、社会科学、工程技术等方面的跨学科集成研究, 重 
视成果在国家、部门、地方、行业等的重大计划制定和实 施中的应用. 在气候变化科学基础方面, 进一步加强海洋 气候变量和环流、气候变化检测归因、气候变化预估研究. 在适应气候变化方面, 应增强人类安全生计和贫困、适应 需求和选择、规划和执行、气候变化经济学研究. 在气候 变化减缓方面, 需要增强与减缓的相关实践方面的研究, 以及中国温室气体提前达峰方面的研究. 科学中的政治最 好还是用科学来回应, 因此要有目标的组织研究, 有要求 的进行发表. 不仅理论上要有根基, 方法论上也要有特点. 由于 IPCC 评估的工作语言是英语, 这就要求中国的研究成 果要以英文发表, 获得国际认可. 否则政府评审意见只是根 据公约文本、政策文件, 没有文献支持, 难于得到采纳.

\section{4 充分借鉴 IPCC 工作程序, 更好地利用科学 辅助决策国内工作}

IPCC 强调科学公正、利益回避等原则. 中国的一些重
大决策一旦涉及部门利益, 以部门为主导就可能出现国家 宏观利益被局部或部门利益打折扣的现象. IPCC 在选题、 文本讨论中都要广泛听取不同利益方的意见, 并将结果在 网上公开, 强调主席团成员、作者的利益回避等. 保证利 益的公正性, 就必须要有利益各方的广泛参与. 这种参与 应该是平等的、制度性的, 还必须要有客观详实的科学、 社会经济分析. 因此, IPCC一套科学评估规范制度在确保 广泛参与性, 提高决策透明度、防范决策主观随意性以及 保障利益公正性等方面都值得中国借鉴. 在国内决策过程 中，充分吸收政府部门、社会团体和公众的意见，充分发 挥不同利益相关方在决策中的作用, 建立政府部门主导、 研究机构和智库咨询、社会公众广泛参与的决策体制, 增 强社会各界应对气候变化的危机意识和参与意识, 将有利 于更快更好地实现决策目标. 另外, 中国第四次气候变化 评估报告也进人了启动程序, 借鉴 IPCC 的经验也将有利 于该工作高效高质量的完成. (2014097)和科技部应急项目第九课题(2016)资助.

\section{推葆阅读文献}

1 Gupta J. The History of Global Climate Governance. Cambridge: Cambridge University Press, 2014

2 Dessler A, Parson E. The Science and Politics of Global Climate Change: A Guide to the Debate. Cambridge: Cambridge University Press, 2009

3 Dong L, Zhang H B. How IPCC affect the international climate negotiation (in Chinese). World Econ Polit, 2014, (8): 64-83 [董亮, 张海 滨. IPCC 如何影响国际气候谈判——种基于认知共同体理论的分析. 世界经济与政治, 2014, (8): 64-83]

4 Houghton J T, Jenkins G J, Ephraums J J. Climate Change: The IPCC Scientific Assessment. Cambridge: Cambridge University Press, 1990

5 IPCC. Climate Change 1995: The Science of Climate Change. Cambridge: Cambridge University Press, 1996

6 IPCC. Climate Change 2001: The Scientific Basis. Contribution of Working Group I to the Third Assessment Report of the Intergovernmental Panel on Climate Change. Cambridge: Cambridge University Press, 2001

7 IPCC. Climate Change 2007: The Physical Science Basis. Contribution of Working Group I to the Fourth Assessment Report of the Intergovernmental Panel on Climate Change (IPCC). Cambridge: Cambridge University Press, 2007

8 IPCC. Climate Change 2013: The Physical Science Basis. Contribution of Working Group I to the Fifth Assessment Report of the Intergovernmental Panel on Climate Change. Cambridge: Cambridge University Press, 2013

9 Zhang X H, Qi Y, Fu S. Impact of IPCC Fifth Assessment Report on 2015 agreement negotiations (in Chinese). China Energy, 2014, 36: 14-17 [张晓华, 祁悦, 傅莎. IPCC 第五次评估报告对 2015 协议谈判的影响分析. 中国能源, 2014, 36: 14-17]

10 Gao Y, Gao X, Zhang X H. $2^{\circ} \mathrm{C}$ temperature rise goal and the evolution of long-term goal of dealing with climate change-From United Nations Framework Convention on Climate Change (UNFCCC) to Paris Agreement (in Chinese). Engineering, 2017, 3: 262-276

11 Zhang Y X, Huang L, Zhou B T, et al. The preliminary interpretation on $1.5^{\circ} \mathrm{C}$ global temperature goal (in Chinese). Adv Clim Change Res, 2017, 13: 299-305 [张永香, 黄磊, 周波涛, 等. $1.5^{\circ} \mathrm{C}$ 全球温控目标浅析. 气候变化研究进展, 2017, 13: 299-305]

12 Zhou B T. IPCC holds global warming $1.5^{\circ} \mathrm{C}$ special syllabus to prepare seminar (in Chinese). Adv Clim Change Res, 2016 , 12: 381 [周 波涛. IPCC 召开全球升温 $1.5^{\circ} \mathrm{C}$ 特别报告大纲编写研讨会. 气候变化研究进展, 2016, 12: 381]

13 Siebenhuener B. How do scientific assessments learn? Part I. Conceptual framework and case study of the IPCC. Environ Sci Policy, 2002, 5: 411-420

14 Pan J H. Scientific argument of national interests and international political compromise (in Chinese). World Econ Polit, 2002, 2: 55-59 [潘家华. 国家利益的科学论争与国际政治妥协. 世界经济与政治, 2002, 2: 55-59]

15 Xiao L L. China's participation, impact and follow-up on IPCC assessment report (in Chinese). Int Outlook, 2016, 8: 59-77 [肖兰兰. 
中国对 IPCC 评估报告的参与、影响及后续作为. 国际展望, 2016, 8: 59-77]

16 Wu C, Jia P J. The voice of China is on the rise-Bibliometric analysis based on IPCC Fifth Assessment Working Group I Report (in Chinese). Adv Clim Change Res, 2014, 10: 65-66 [吴灿，贾朋群. 中国的声音在提高一基于 IPCC 第五次评估第一工作组报告的文 献计量分析. 气候变化研究进展, 2014, 10: 65-66]

17 Zhen Q H, Wang X L, Wu C, et al. IPCC Fifth Assessment Report Working Group II Report citation analysis in China (in Chinese). Adv Clim Change Res, 2014, 10: 208-210 [郑秋红, 王小玲, 吴灿, 等. IPCC 第五次评估报告第二工作组报告中国引文计量分析. 气候变 化研究进展, 2014, 10: 208-210]

18 Li J H, Wu C, Zheng Q H. IPCC Fifth Assessment Report Working Group III Report citation analysis in China (in Chinese). Adv Clim Change Res, 2014, 10: 355-357 [李婧华, 吴灿, 郑秋红. IPCC 第五次评估报告第三工作组报告中国引文计量分析. 气候变化研究进 展, 2014, 10: 355-357]

19 Zhang H B. China's position in international climate change negotiations: Continuity and change and its causes (in Chinese). World Econ Polit，2006，10：36-43 [张海滨. 中国在国际气候变化谈判中的立场：连续性与变化及其原因探析. 世界经济与政治，2006，10: 36-43]

20 Gao Y. Climate change response to the situation in China after Paris Climate Change Conference (in Chinese). Adv Clim Change Res, 2017, 13: 89-94 [高云. 巴黎气候变化大会后中国的气候变化应对形势. 气候变化研究进展, 2017, 13: 89-94]

21 Zhang Y X, Chao Q C, Zheng Q H. The withdrawal of the U.S. from the Paris Agreement and its impact on global climate change governance (in Chinese). Adv Clim Change Res, 2017, 13: 407-414 [张永香, 巢清尘, 郑秋红, 等. 美国退出《巴黎协定》对全球气候治 理的影响. 气候变化研究进展, 2017, 13: 407-414] 


\title{
Lessons China can learn from the interactions between climate change research and governance
}

\author{
Yongxiang Zhang ${ }^{1 *}$, Qingchen Chao ${ }^{1}$, Jinghua $\mathrm{Li}^{2}$, Lei Huang ${ }^{1 *} \&$ Botao Zhou ${ }^{1,3}$ \\ ${ }^{1}$ National Climate Center, China Meteorology Administration, Beijing 100081, China; \\ ${ }^{2}$ China Meteorological Administration Training Centre, Beijing 100081, China; \\ ${ }^{3}$ Collaborative Innovation Center on Forecast and Evaluation of Meteorological Disasters, Nanjing University of Information Science \& Technology, \\ Nanjing 210044, China \\ *Corresponding authors, E-mail: zhangyx@cma.gov.cn; huanglei@cma.gov.cn
}

Climate change has attracted the general concern of the international community. Global actions on climate change are based not only in the science, but also involve domestic and international economics and politics. Here we review the interactions between the Intergovernmental Panel on Climate Change (IPCC) assessment reports and the development of climate policy under the United Nations Framework Convention on Climate Change (UNFCCC). There are inextricable links between the scientific research and political processes. The systematic IPCC assessment reports provide important scientific evidence and conclusions on which the Parties to the UNFCCC have based their negotiations. An important example is policies considering adaptation to long term climate change. Conversely, the UNFCCC negotiations direct research direction and foci for scientific communities and the IPCC. China has participated in global climate change science and policy activities for years, but although its scientific and political contribution has increased, its research activity still lags behind that of Europe and the United States. The percentage of mainland Chinese publications cited in the IPCC's 5th Assessment Report (AR5; 2013), Working Group I (Physical Science Basis), was 2.8\%, a doubling from the percentage cited in the Working Group I report from the 4th Assessment Report (2007). For the AR5 second and third working group reports (Impacts, Mitigation), the lead authors were 1.3\% and 1.6\% respectively. Some core fields, such as the global sequence of surface air temperature data and the accumulated emission space of $2^{\circ} \mathrm{C}$, lack expert and Chinese input. With the rapid development of its economy, China will assume more responsibility in global climate change policy. However current domestic scientific research cannot fully support China's transition to a more important global role. More responsibility needs to be matched with more high level capacity. In the future, China should learn from the historical interactions between the international scientific research community (including the IPCC) and global climate change governance (both international and domestic policy making). First, the national long term climate policy should systematically consider the relationships between science and politics, since climate change issues are different from others. Without the confident support from scientific research, it is hard to make any decisions. Second, it should take advantage of expertise in think tanks. Think tanks have played very important role in the West. Given the unprecedented complexity of climate diplomatic decisions, there is an urgent need for high level think tanks to provide forward-looking, agile, accurate, credible, high-quality and efficient support for decision-making. Third, China should continue to maintain and increase investment in climate related scientific research and integrative activities, publication of academic achievements and international recognition. Climate change is a global and systematic issue. It is essential to accelerate the integration of information across different disciplines (natural sciences, social sciences, engineering and technology) and to pay attention to the transformation from basic disciplinary research results into policy recommendations at the state, department, locality and industrial levels. Since the working language assessed by IPCC is English, this requires that the research results of China should be published in English with international recognition. Fourth, China should make full use of the IPCC working procedures to improve scientific decision making for domestic work. The IPCC scientific evaluation norms system ensures broad participation, improve transparency in decision-making, prevent subjective decision-making and ensure a balance of interests. In the domestic decision-making process, it is useful to absorb the opinions of government departments, social organizations and the public, give full play to the role of different stakeholders in decision-making, and establish a decision-making system dominated by government departments, consulting institutions and think tanks, while involving the general public extensively. All sectors of society need to improved awareness of climate change to respond to this crisis, and broader participation will help achieve faster and better decision-making goals.

Intergovernmental Panel on Climate Change (IPCC), United Nations Framework Convention on Climate Change (UNFCCC), global governance, China's strategy

doi: 10.1360/N972017-01345 